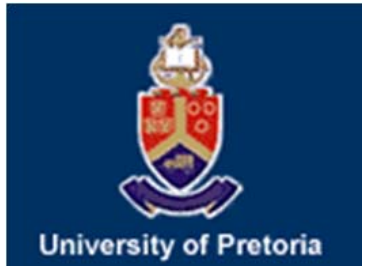

University of Pretoria Department of Economics Working Paper Series

Debunking the Myth that a Legal Trade will Solve the Rhino Horn Crisis: A System Dynamics Model for Market Demand

Douglas J. Crookes

University of Pretoria

James N. Blignaut

University of Pretoria

Working Paper: 2015-33

May 2015

Department of Economics

University of Pretoria

0002, Pretoria

South Africa

Tel: +27 124202413 


\title{
Debunking the myth that a legal trade will solve the rhino horn crisis: A system dynamics model for market demand
}

\author{
Douglas J. Crookes*\& James N. Blignaut ${ }^{\dagger}$
}

May 26, 2015

\begin{abstract}
There is considerable debate in the literature over whether or not to legalise the trade in rhino horns. Here a system dynamics model is developed that considers five components: rhino abundance, rhino demand, a price model, an income model and a supply model. The results indicate that income elasticities are much greater than previously observed, while demand is relatively insensitive to price. At the same time, legalising the trade without income modification policies did not prevent extinction. The theory of s-curve growth may provide some indications of future growth patterns of Asian economies. Results suggest that, even though the demand curve for rhino horn may be downward sloping as conventional theory predicts, non-conventional demand management strategies may be more effective than price orientated demand curve strategies such as trade legalisation in curbing supply.
\end{abstract}

\section{Introduction}

There is much debate in the conservation literature over whether or not to legalise the trade in rhino horns. Biggs et al. (2012) write that a legal trade can only work if, among other things, "the demand does not escalate to dangerous levels as the stigma associated with the illegality of the product is removed." A number of authors (e.g. Collins et al 2013; Prins and Okita-Ouma, 2013) emphasise uncertainties over responses of market demand to a legal trade. If demand is positively sloping, by an Anthropogenic Allee Effect (AAE), then species extinction could actually be exacerbated by demand reduction strategies (Hall et al 2008). On the other hand, Biggs et al (2012) argue demand is

\footnotetext{
*Email: dcrookes@outlook.com, Affiliation: Department of Economics, University of Pretoria

${ }^{\dagger}$ Email: jnblignaut@gmail.com, Affiliation: Department of Economics, University of Pretoria
} 
downward sloping (but inelastic). They argue, therefore, that demand reduction strategies would actually reduce the supply of rhino horns to the market.

It is therefore important to develop a model to estimate the response of consumers to changes in demand, prices and income. Rhino horn price and income elasticities were estimated by Milner-Gulland (1993) using multivariate linear regression. Her model showed that the price coefficient was insignificant while the income elasticity was 1.06, indicating that rhino horns were luxury goods. However, market demand have increase dramatically in the past 20 years. We therefore need to ascertain whether or not these conditions still hold. Furthermore, estimation of market dynamics requires an understanding of how different components (rhino population, preferences, income and price) interact with each other. We therefore need to develop a model to consider the market dynamics associated with the rhino horn trade in order to estimate several crucial elasticities (price, income and consumption). However, instead of using the standard regression techniques to estimate elasticities, we develop a systems model that replicates the known behaviour of the system. Once the elasticities are known, we use the model to answer "what if" type questions on the behaviour of the system. In particular, we want to know the effect of legalising the trade in rhino horn on all key market participants (rhino horn consumers and game reserve "suppliers").

The number of studies that have utilised system dynamics models for wildlife populations is too numerous to review in its entirety, but here is a selection. Chen et al (2014) develop a model that simulates the effect of air pollution on habitat, which in turn affects the migratory behaviour of birds. Beall and Zeoli (2008) model the dynamics of Greater sage grouse populations in Western North America. Land management decisions are the main driver of population declines. Semeniuk et al. (2010) examine the effect of tourism on stingray populations. An interesting feature of the model is the use of a logistic growth formulation to model a density dependent tourism growth function. As far as mammals are concerned, Faust et al (2004) develop a stochastic, two sex, four stage model for grizzly bears in zoos, as well as the Yellowstone National Park. On the African continent, Weller et al (2014) model African penguin populations subject to a number of pressures, including oil spills and competition for food from the fishing industry. An age structured model characterises the penguin population dynamics.

\section{The model}

There are five components of the market model (Figure 1). These are: 1) a population model determining the dynamics of rhino abundance; 2) an income model determining the response of rhino horn demand to changes in income; 3 ) a price model, evaluating the effect of price changes on demand; 4) a demand function that combines the income and price models, and 5) a supply model, considering the effect on game farm profitability of either legalised trade or no trade. We will now consider each of these components in turn. 


\section{$2.1 \quad$ Population model}

The model utilises the population model of Milner-Gulland and Leader-Williams (1992), which is in effect a density dependent logistic model.

$$
f(x)=r x\left(1-\left[\begin{array}{l}
x \\
k
\end{array}\right]^{z}\right)-h
$$

Where $\mathrm{k}$ is the carrying capacity, $\mathrm{r}$ is the intrinsic growth rate, $\mathrm{x}$ is the rhino population, $\mathrm{z}$ is a density dependent term and $\mathrm{h}$ is the harvest (poaching) rate.

\section{$2.2 \quad$ Income}

There are various theories of economic growth. We need a growth theory that accurately represents the Asian economies where the demand for rhino horn is prevalent. One such theory is that of Emeritus Professor Lim Ching Yah. Professor Lim has over 40 years' experience as an academic researcher in pursuit of the goals of economic development and social upliftment (Sng, 2010). He developed the s-curve growth hypothesis (e.g. Lim 2005), which was subsequently empirically verified through econometric analysis (Sng, 2010).

The s-curve growth theory, as the name suggests, holds that an economy grows in a sigmoid manner. A typical economy grows in three stages (Figure 2): initially, an economy is characterised by low income and low growth (turtle economy). Over time, however, growth increases rapidly along with income (horse economy). Stage III is reached when income is high and growth slows (elephant economy). The data indicates that this growth pattern is highly indicative of East Asian economies (Lim 2005).

The current model is developed for Vietnam, a major consumer of rhino horn products from the African continent (Milliken and Shaw, 2012). Income growth follows a logistic function similar to the rhino population model:

$$
f(y)=i y\left(1-\frac{y}{y_{\max }}\right)
$$

The growth rate $\mathrm{i}$ and maximum income $\mathrm{Y}_{\max }$ were unknown and so were allowed to vary until the best fit with the historical data was achieved. The effect of income on demand is given by the following function:

$$
y_{t}^{D}=e^{\varepsilon_{Y} * I n}\left(y t / y_{R}\right)
$$

Where $\varepsilon_{y}$ is the elasticity of demand with respect to income, $\mathrm{y}_{t}$ is the income data emanating from the logistic growth function and $\mathrm{y}_{R}$ is a reference income that needs to be empirically determined from the data.

\subsection{Price function}

The price function uses a different approach to determining changes in prices over time, but is similar to the income function in the way that the effect of 
price changes on demand is modelled, except that the price elasticity of demand is negative rather than positive:

$$
p_{t}^{D}=e^{-\varepsilon_{p} I n}\left({ }^{P t} / P_{R}\right)
$$

We modelled the effect of a positive price elasticity of demand, to test for an Anthropogenic Allee Effect (AAE), but this did not fit the historical data very well, although extinction occurred much sooner than under the baseline. For negative price elasticity, demand was insensitive to changes in price so we conclude, as per Milner-Gulland (1993) that price is not an important driver of rhino horn demand.

\subsection{Demand function}

The demand for rhino horn is then a simple combination of price effects and income effects in the model:

$$
D_{t}^{H}=D_{R} \Delta \omega_{t}^{D}
$$

Where $D_{R}$ is a demand coefficient, and $\Delta \omega^{D}$ is the net change in price and income effects $\left(y_{t}^{D}\right.$ and $\left.p_{t}^{D}\right)$. A consumption function that also influenced demand through an income effect was also attempted, but this also did not have a significant impact on the model dynamics.

\subsection{Game reserves}

Game farm profitability is estimated taking into consideration both non-horn income and horn income. Non-horn income is the income from trophy hunting, live sales, game products and eco-tourism. Not all rhinos encompass all these values. For example, rhinos on public land may only be used for live sales and ecotourism, while certain private game farms may emphasise trophy hunting and game products. Averaging across all rhino uses, gives an approximate value of $\$ 364$ per rhino per annum (Appendix 1).

Income from dehorning is estimated as follows:

$$
I^{H}=\gamma^{H} x_{t} W^{H} p_{t}^{W}
$$

Where $\gamma^{H}$ is the proportion of rhinos dehorned, $\mathrm{x}_{t}$ is the total rhino population in time t, $W^{H}$ is the mass of rhino horn removed per annum and $p_{t}^{W}$ is the wholesale price of rhino horn in time t. Following Milner-Gulland (1999), $\gamma^{H}$ is set at 1 as it is optimal to dehorn all rhinos and $W^{H}$ is set at $1 \mathrm{~kg}$.

For game farm management costs, we utilise the non-linear cost model of Allen (2002), such that management costs are modelled as a non-linear function of effort:

$$
c(E)=a E^{2}
$$


Where a is an unknown parameter that needs to be estimated. Hall (2012) provides detailed farm level cost rhinos, from which it is possible to calculate management costs for 2011 subject to dehorning and in the absence of dehorning. Using optimisation, a is estimated to be 0.026 under a de-horning strategy, and 0.022 under no dehorning De-horning costs are calculated from Hall (2012), see Appendix 1.

\section{Parameterising the model}

The parameters used in the model are summarised in Table 1 . Here we differentiate between parameters that are exogenous to the model, and parameters that are endogenous. Endogenous data represents data generated by the model itself, and represents two kinds: data through calibrating the model to find the best fit using the Vensim software, and data derived through optimisation, either from within Vensim (Optimisation A) or by using Excel Solver (Optimisation B). Calibration is used where a more imprecise fit is sufficient, whereas optimisation is required to obtain a more precise fit, for example for the estimation of elasticities.

\section{Results}

\subsection{Elasticities}

The system dynamics model we developed (Figure 1) indicates that demand is not sensitive to changes in the price of rhino horn. This is consistent with the observations of Milner-Gulland (1993). The implication of this is that lifting the trade ban, even if it results in a reduction in rhino horn price, will not alleviate demand.

Income elasticities are positive, and greater than those estimated by MilnerGulland (1993). We estimate an income elasticity of 3.445, which indicates that rhino horns are more of a luxury good, with consumption rising with increased income. This suggests that income policies may be successful in managing the rhino horn trade.

We therefore use the systems dynamics model to examine two models. The first (Policy series 1x) is an equilibrium model based on Allen's (2002) non-linear property rights model, and the second (Policy series $2 \mathrm{x}$ ) is a disequilibrium model to investigate the effect of changes in market demand on game farm profitability. Table 2 summarises the different policies examined. These include: a baseline simulation (no legal trade, no income reduction); policy simulation 1A, 2A (legalisation of the trade, no income reduction); policy simulation 1B, 2B (legalisation of the trade, income reduction); and policy simulation 1C, 2C (no legalised trade and income reduction in consumer nations). For each of these policies we look at the effect on rhino abundance and the profitability of game farming, as measured by the net present value of game farms between 1980 and 2050 . 


\subsection{Equilibrium model}

One way of exploring the implication of a legalisation of the trade is to consider Allen's non-linear property rights model (Allen 2002). The model, populated with data from our study, shows the different values and costs associated with game farming subject to poaching (Figure 3). The 45 degree line indicates the benefits from wildlife management, whereas the curvilinear line indicates the management costs subject to poaching. Where costs and revenues intersect (the solid black line in Figure 3, which we will call $\mathrm{V}^{H}$ ), is the maximum value that would make private ownership viable. To the right of this intersection, public ownership is the preferred management strategy as management costs would exceed benefits. We use Allen's model to consider in greater detail the policy option of legalising the trade with and without income reduction.

\subsubsection{Policy 1A: De-horning with trade, no CBM}

The first best threshold value below which private sector game farms are viable $\left(\mathrm{V}^{H}\right)$ is $\$ 31,870 / \mathrm{kg}$, which is marginally lower than the 2013 wholesale price of rhino horn $(\$ 32,500 / \mathrm{kg})$ (Figure 3 ). This suggests that a legal trade would not result in a viable and profitable private sector at the prevailing market price once management and enforcement costs are taken into consideration. However, the actual value accruing to game farms (the so called second best value) is negative, $-\$ 5,950 / \mathrm{kg}$, since the cost of enforcement at that price is higher than the income earned $(\$ 38,450 / \mathrm{kg})$. The net present value of game farming under this scenario is $-\$ 137$ million at a discount rate of 0.2 and $-\$ 172$ million at a discount rate of 0.14 (Figure 4).

\subsubsection{Policy 1B: De-horning with trade, price reduction}

Our analysis (Figure 3) indicates that a legalisation of trade would increase game farm profitability compared with no price reduction. A shift in the wholesale price of rhino horn from $\$ 32,500 / \mathrm{kg}$ down to $\$ 27,665 / \mathrm{kg}$ would result in the profit maximisation solution for game reserves (Figure 3). At this level, the costs of enforcement are reduced as a result of dehorning, and the reduction in costs exceeds the reduction in price, making this the optimal de-horning strategy. The value accruing to game farms from this (the so called second best value) would be $\$ 18,460 / \mathrm{kg}$ (the dotted line in Figure 3 ). The cost of management and enforcement would be $\$ 9,205 / \mathrm{kg}$ at this price.

\subsubsection{Policy 1C: No legalised trade, de-horning}

A third strategy, involves the de-horning of rhino without legalisation of the trade. Under Allen's model, this would reduce the first best value to $\$ 364 / \mathrm{kg}$, and would reduce the management costs significantly. Our analysis suggests that this would produce a viable private sector. The NPV under this scenario is $\$ 8$ million at a discount rate of 0.2 , and $\$ 10.5$ million at a discount rate of 0.17 (Figure 4). 


\subsection{Disequilibrium model}

\subsubsection{Status quo: no trade, no $C B M$}

Under the baseline, income rises and so does expected demand for rhino horn products, and rhino abundance declines to zero. This is consistent with the findings of Di Minin et al (2015). The effect of these declines on the profitability of game reserves is ambiguous, and depends on the discount rate (return on capital). For low discount rates (i.e. $\delta<0.18)$, profitability declines $(\mathrm{NPV}<0)$ over the next 5-10 years. However for higher returns on capital (e.g. $\delta=0.2$ ), total NPV of rhino farming stabilises at around $\$ 6$ million (Figure 4).

\subsubsection{Policy 2A: Trade, no $C B M$}

Under a policy of legalising the rhino horn trade (but without consumer behaviour modification), rhino abundance continues to be driven to extinction, while game farm profitability is positive for all values of the discount rate (Figure 4). The incentive therefore for game reserves to harvest rhino horn to extinction, while maximising profits by taking the maximum amount of rhino horn from each animals.

\subsubsection{Policy simulation 2B: legalisation of trade and $C B M$}

A reduction in income in consumer nations and a legalisation of the trade could have "win-win" implications for conservationists as well as game farmers, however it is a risky strategy as the income reduction would need to be sufficient to reduce demand, while legalising the trade may actually stimulate demand. Furthermore, the NPV for Game Reserves from without CBM (Policy simulation $2 \mathrm{~A}$ ) is greater than the NPV for trade legalisation with CBM (Policy 2B, see Figure 4), therefore encouraging a switch to a 'banking on extinction' scenario (Mason et al. 2012). Under CBM, rhino abundance stabilises at around 0.5K, whereas without CBM extinction is likely (Figure 4).

\subsubsection{Policy simulation 2C: No trade, CBM}

This strategy assumes no trade, but models the effect of CBM to induce the shift in price. A reduction of income has the effect of improving the sustainability of rhinos, while game farm profitability stabilises at between $\$ 8$ and $\$ 9$ million (Figure 4).

\subsection{Optimal de-horning strategy}

The previous section has indicated that no trade and CBM is the optimal strategy. These results are consistent and similar for both the equilibrium model as well as the disequilibrium model. The question therefore remains, can this result be achieved through de-horning rather than through market based approaches? We therefore need to consider the optimal de-horning strategy for the poacher and the game farm. 
Using the optimal de-horning model of Milner-Gulland et al (1992), we estimate the optimal dehorning strategy of game farmers and poachers. Following these authors, horn growth follows Von Bertalanffy growth function and game farms and poachers seek to maximise profits subject to a Faustmann growth model, where $P V=(V(T)-c) /\left(e^{r T}-1\right)$ is the site value, where $V(T)-c$ is the net stumpage value and $\mathrm{V}(\mathrm{T})=\mathrm{p}^{*} \mathrm{w}(\mathrm{t})$ is the value of horn at a specific weight. Figure 4 indicates the optimal harvesting strategy for both game reserves and poachers, using data from our study. The results indicate that, while it is optimal for game farms to harvest after $\mathrm{T}=1.5$ years, for poachers it is optimal to kill a rhino and harvest its horn, even at very low rotation intervals (Figure $5)$. This suggests that, even if a poacher encounters a dehorned rhino, it is still optimal to kill the rhino and take what is left of the stump. This casts doubt on the effectiveness of a dehorning strategy.

\section{Discussion}

Conventional wisdom holds that demand reduction strategies would be effective in reducing supply, where demand is downward sloping. Our study shows that, that even if the demand curve is negative and inelastic as hypothesised by Biggs et al (2012), conventional demand reduction strategies that influence the price of rhino horn to the market may not be successful in curbing supply. Our model indicates that less conventional demand management strategies (such as consumer education, behaviour modification), appear to be more effective strategies in managing rhino horn demand than legalising the trade in rhino horns. In making this bold claim, we need to look broader than this study for evidence to substantiate this. First we consider the theoretical basis for this claim by considering what is hypothesised from Lim's growth theory, and secondly, we consider the supporting evidence for non-conventional demand reduction strategies.

An extension of Lim's s-curve hypothesis is his theory of the drivers of growth (the so-called EGOIN theory). He identifies 5 drivers: entrepreneurship (E) government $(\mathrm{G})$, ordinary labour $(\mathrm{O})$, investment in physical capital (I) and natural resources $(\mathrm{N})$. As far as natural resources are concerned, he states that:

"here, we refer to utilized N. Unutilized N remains unutilized, and does not contribute to GDP growth level and growth rate. Natural resources normally refer to wasting assets like fossil oil, gold, tin, coal, iron-ore and diamond mines, and non-wasting or renewable natural resources like palm oil, rubber, sugar, wheat, rice, soya beans, corn, etc. However, we must also include location as a natural resource. Locational advantages like proximity to a river mouth or the cross-roads of shipping routes also confer certain advantages to the economic centres concerned." (Lim, 2012, p.7).

Rhino horn products could potentially fall under wasting (non-renewable) or non-wasting (renewable) commodities, depending on how the horns are harvested. He argues that development results in better use of natural resources. Natural resources under turtle economies are not well utilised or lacking, under 
horse and elephant economies well utilised (see Sng, 2010, Table 1.1 page 5). Although the focus of the theory is on more efficient use of natural resources, a feature of many developed economies in the West is a shift to more sustainable use of natural resources. This is the challenge for Asian economies that are focussed more on efficient resource extraction aimed at maximising growth, and focussed less on sustainable harvesting practices. Education at all levels of society is therefore very important in this regard.

Secondly, we consider the empirical evidence of non-conventional demand reduction strategies. The idea of consumer behaviour modification is not new. Already in 2012, Miliken and Shaw made the following appeal:

"There is a compelling need to develop options for a campaign-type approach to demand reduction in Viet Nam. In this regard, well-researched strategies that target specific consumer groups with appropriate messages and influential delivery mechanisms need to be identified and implemented with the objective of influencing consumer behaviour away from rhino horn use. In particular, the evolving role of rhino horn as a non-essential lifestyle attribute needs to be directly challenged as an unacceptable form of social behaviour. Demand reduction should focus on dispelling obvious myths about the efficacy of rhino horn, promote acceptable alternatives if appropriate and create awareness of the consequences of illegal trade and usage and the conservation implications of continued rhino horn trade." (Milliken and Shaw (2012), p. 148)

Apparently in response to this appeal, a public education and awareness campaign jointly implemented under a partnership between Humane Society International and the Viet Nam Convention on International Trade in Endangered Species of Wild Fauna and Flora (CITES) Management Authority has been in operation in Vietnam since August 2013. There is some evidence for its success in reducing demand (HSI, 2014), although other studies have appealed for more monitoring data to confirm this (Roberton, 2014).

In conclusion, our study reinforces the findings of Milner-Gulland (1993) that price is an insignificant driver for demand and that demand is income responsive, except that rhino horn is now more of a luxury good than observed in her study more than 20 years ago. Lifting the trade ban seeks to influence demand through the price mechanism, and is likely to be less effective than non-

price policies. International pressure to change perceptions from status symbol to pariah could well be decisive in conserving rhino populations.

\section{References}

[1] Allen D.W., 2002. The Rhino's horn: incomplete property rights and the optimal value of an asset, J. Legal St., 31: 339-358.

[2] Beall, A., Zeoli, L., 2008. Participatory modeling of endangered wildlife systems: Simulating the sage-grouse and land use in Central Washington. Ecological Economics 68 (1-2), pp. 24-33 
[3] Biggs D., Courchamp F., Martin R. \& Possingham H.P, 2013. Legal Trade of Africa's Rhino Horns, Science 339: 1038-1039.

[4] Chen, H., Chang, Y.-C., Chen, K.-C., 2014. Integrated wetland management: An analysis with group model building based on system dynamics model. Journal of Environmental Management 146, pp. 309-319

[5] Collins, A, Fraser, G. \& Snowball, J, 2013. Rhino Poaching: Supply and Demand Uncertain, Science 340:1167.

[6] Di Minin E., Laitila J., Montesino-Pouzols F., Leader-Williams N., Slotow R., Goodman P.S., Conway A.J., and Moilanen A., 2015. Identification of Policies for a Sustainable Legal Trade in Rhinoceros Horn Based on Population Projection and Socioeconomic Models. Cons Bio, In press.

[7] Faust, L.J., Jackson, R., Ford, A., Earnhardt, J.M., Thompson, S.D., 2004. Models for management of wildlife populations: Lessons from spectacled bears in zoos and grizzly bears in Yellowstone. System Dynamics Review 20(2), pp. $163-178$

[8] Hall C.M.S, 2012. An investigation into the financial feasibility of intensive commercial white rhino farming in South Africa. Faculty of Engineering, Built Environment and Information Technology, University of Pretoria

[9] Hall R.J., Milner-Gulland E.J., Chourchamp F., 2008. Endangering the endangered: The effects of perceived rarity on species exploitation. Conservation Letters 1: 75-81

[10] Humane Society International (HSI), 2014. Demand for Rhino Horns in Viet Nam Decreases as a Result of Humane Society International and Viet Nam CITES Management Authority Partnership Campaign, Poll Says. URL: http://www.hsi.org/assets/pdfs/vietnam-rhino-horn-campaign-pollresults.pdf (Accessed: 29-01-2015).

[11] Leader-Williams, N., 1992. The world trade in rhino horn: a review. TRAFFIC International, Cambridge.

[12] Lim C.Y., 2005. Economic theory and the East Asian region. The Singapore Economic Review, Vol. 50, Special Issue, 495-512

[13] Lim C.Y., 2012. The Trinity Growth Theory: A Theory of Wealth and Poverty. EGC Report No: 2012/03. Nanyang Technological University, Singapore.

[14] Mason, C.F., Bulte E.H., and Horan R.D., 2012. Banking on extinction: endangered species and speculation, Oxford Review of Economic Policy, 28 (1), $180\{192$.

[15] Milliken, T and Shaw, J, 2012. The South Africa-Vietnam rhino horn trade nexus: A deadly combination of institutional lapses, corrupt wildlife industry professionals and Asian crime syndicates. TRAFFIC, Johannesburg. 
[16] Milner-Gulland E. J., Beddington J. R. and Leader-Williams N., 1992. Dehorning African Rhinos: A Model of Optimal Frequency and Profitability. Proceedings: Biological Sciences, Vol. 249 (1324): 83-87

[17] Milner-Gulland E.J and Leader-Williams N., 1992. A model of incentives for the illegal exploitation of black rhinos and elephants: poaching pays in Luangwa Valley, Zambia. Journal of Applied Ecology 29: 388-401.

[18] Millner-Gulland, E.J., 1993. An econometric analysis of consumer demand for ivory and rhino horn. Environ. Res. Econ. 3, 73-95.

[19] Milner-Gulland EJ, 1999, How many to dehorn? A model for decisionmaking by rhino managers, ANIMAL CONSERVATION, Vol: 2, Pages: 137-147, ISSN: 1367-9430

[20] Prins H.H.T. and Okita-Ouma B., 2013. Rhino Poaching: Unique Challenges. Science 340: 1167-1168

[21] Roberton, S.I., 2014. Has Demand for Rhino Horn Truly Dropped in Vietnam? National Geographic, 3 November 2014.

[22] Semeniuk, C.A.D., Haider, W., Cooper, A., Rothley, K.D., 2010. A linked model of animal ecology and human behavior for the management of wildlife tourism. Ecological Modelling 221 (22), pp. 2699-2713

[23] Sng, Hui-Ying 2010. Economic Growth and Transition: Econometric Analysis of Lim's S-Curve Hypothesis (Economic Growth Centre Research Monograph Series, Vol. No. 1). World Scientific, Singapore.

[24] Turpie J., and Joubert A., 2001. Estimating potential impacts of a change in river quality on the tourism value of Kruger National Park: An application of travel cost, contingent and conjoint valuation methods. Water SA, 27(3), 387-398

[25] Van der Merwe, P. and M. Saayman. 2003. Determining the economic value of game farm tourism. Koedoe 46(2): 103-112

[26] Vecchiatto, P., 2013. Government may auction stockpile of rhino horn. Business day live, 03 July 2013

[27] Weller, F., Cecchini, L.-A., Shannon, L., Sherley R.B., Crawford R.J.M., Altwegg R., Scott L., , Stewart, T., Jarre, A. 2014. A system dynamics approach to modelling multiple drivers of the African penguin population on Robben Island, South Africa. Ecological Modelling 277, pp. 38-56 
Table 1: Parameters used in the model

\begin{tabular}{|c|c|c|c|c|}
\hline Parameter & Symbol & Value & Units & Reference \\
\hline \multicolumn{5}{|l|}{ Endogenous variables } \\
\hline Income elasticity & $\varepsilon_{\mathrm{y}}$ & 3.445 & Dimensionless & Optimisation A \\
\hline Price elasticity & $\varepsilon_{\mathrm{p}}$ & 0.1 & Dimensionless & Calibration \\
\hline Reference income & $y_{R}$ & 840 & dollar/person & Calibration \\
\hline Carrying capacity & $\mathrm{K}$ & 50000 & Rhino & Calibration \\
\hline Non-linear cost coefficient & $A$ & 0.026 & dollar/rhino/year & Optimisation B \\
\hline \multicolumn{5}{|l|}{ Exogenous variables } \\
\hline Dehorning costs & & 826 & dollar/rhino/year & $\begin{array}{l}\text { Own calculations (see } \\
\text { Appendix) }\end{array}$ \\
\hline Mass of horn removed & $W^{H}$ & 1 & $\mathrm{~kg} / \mathrm{rhino}$ & Milner-Gulland (1999) \\
\hline Share of retail price & & 0.11 & Dimensionless & $\begin{array}{l}\text { Own calculations based on } \\
\text { Vecchiatto (2013) }\end{array}$ \\
\hline $\begin{array}{l}\text { Income per rhino no } \\
\text { dehorning }\end{array}$ & & 364 & dollar/rhino/year & $\begin{array}{l}\text { Own calculations (see } \\
\text { Appendix) }\end{array}$ \\
\hline Discount rate & $\delta$ & 0.2 & $1 /$ year & $\begin{array}{l}\text { Mean; Milner-Gulland et al } \\
\text { (1992) }\end{array}$ \\
\hline Proportion rhino dehorned & $\gamma^{H}$ & 1 & 1/rhino/year & Milner-Gulland (1999) \\
\hline Initial price (1980) & & 1762 & dollar/kg & $\begin{array}{l}\text { Average prices from data } \\
\text { in Leader-Williams (1992) }\end{array}$ \\
\hline Fowler (curvilinear) factor & $z$ & 7 & Dimensionless & $\begin{array}{l}\text { Milner-Gulland \& Leader- } \\
\text { Williams (1992) }\end{array}$ \\
\hline intrinsic growth rate & $r$ & 0.061 & Dimensionless & Unpublished data \\
\hline
\end{tabular}

Table 2: Policy experiments conducted

\begin{tabular}{|l|c|c|c|c|c|c|}
\hline \multirow{2}{*}{} & \multicolumn{3}{|c|}{ No legalised trade } & \multicolumn{3}{c|}{ Legalised trade } \\
\cline { 2 - 7 } & Equilibrium & Disequilibrium & \multicolumn{2}{c|}{ Equilibrium } & Disequilibrium \\
\cline { 2 - 7 } & Policy & SBV $(\$ / \mathrm{kg})$ & Policy & Policy & SBV $(\$ / \mathrm{kg})$ & Policy \\
\hline No CBM & & & Baseline & Policy 1A & $-5,954$ & Policy 2A \\
\hline CBM & Policy 1C & 361 & Policy 2C & Policy 1B & 18,458 & Policy 2B \\
\hline
\end{tabular}

Notes: Policy $1 \mathrm{x}$ strategies are the game reserve level strategies, whereas Policy $2 \mathrm{x}$ are market based strategies. $\mathrm{CBM}=$ consumer behaviour modification; $\mathrm{SBV}=\mathrm{Second}$ best value 
Figure 1: Stock flow diagram of the market model

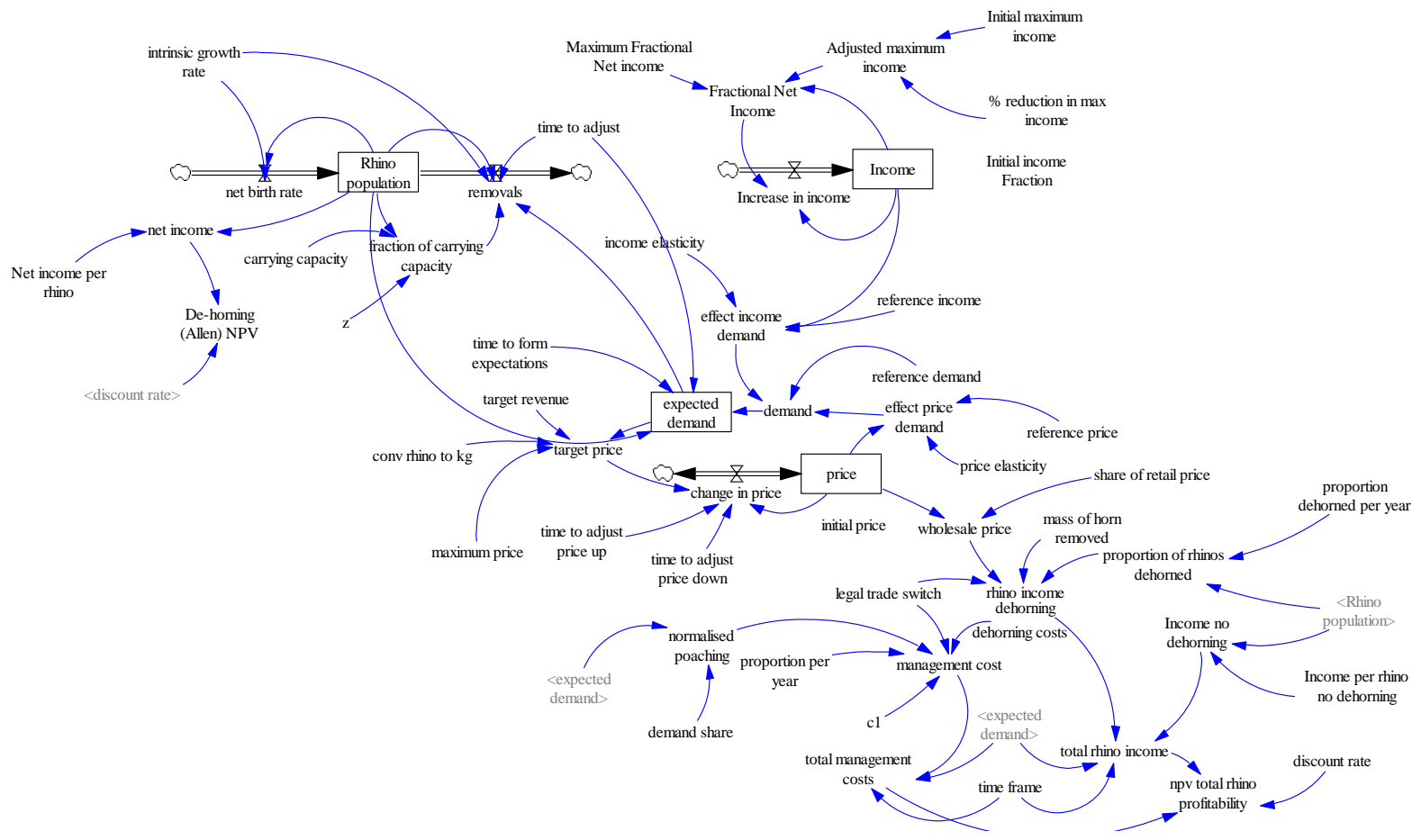

Figure 2: S-curve of economic development

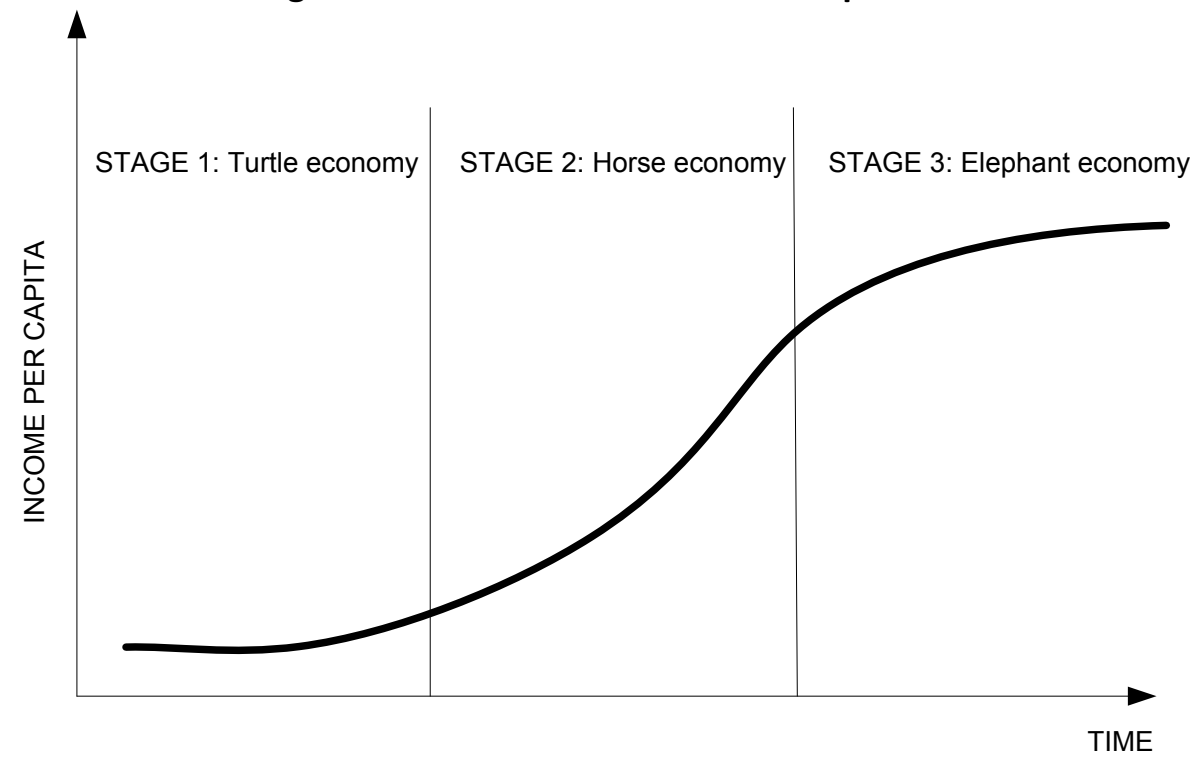

Source: Sng, 2010. 
Figure 3: Game farm profitability

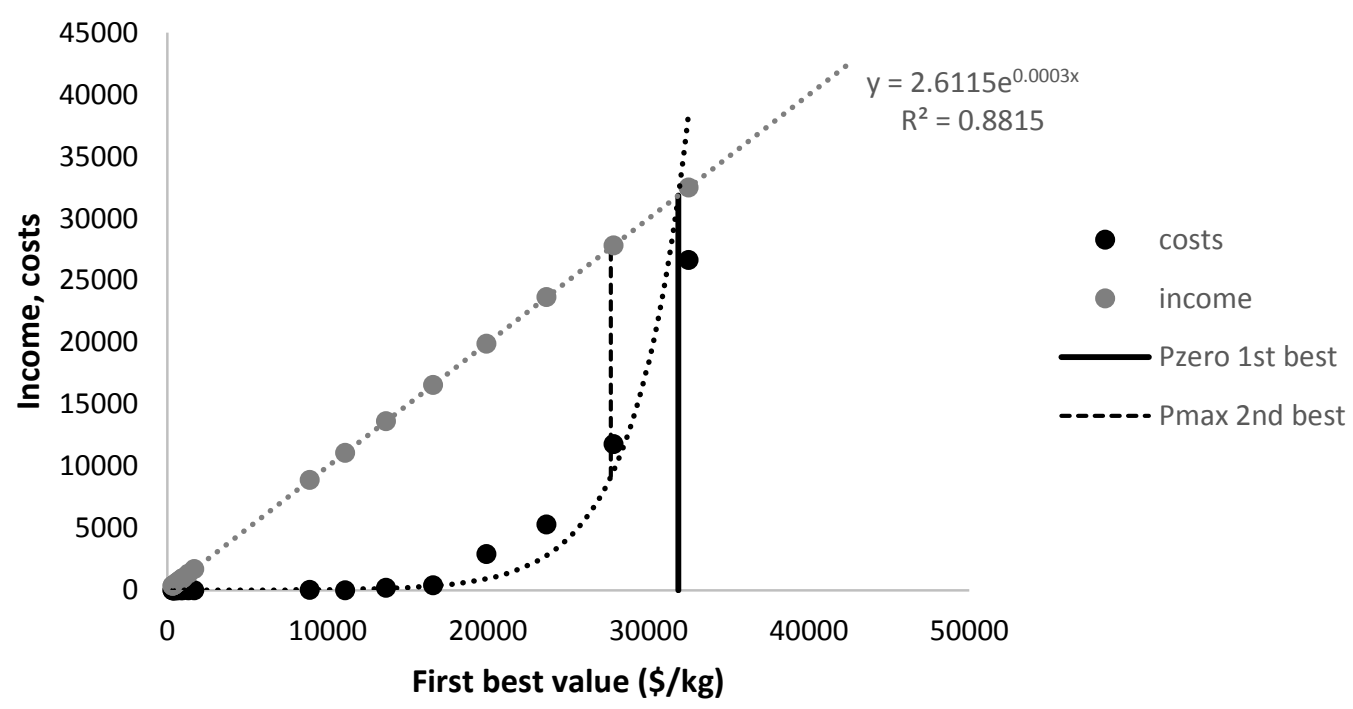

Figure 4: Game farm profitability and rhino abundance under different policies
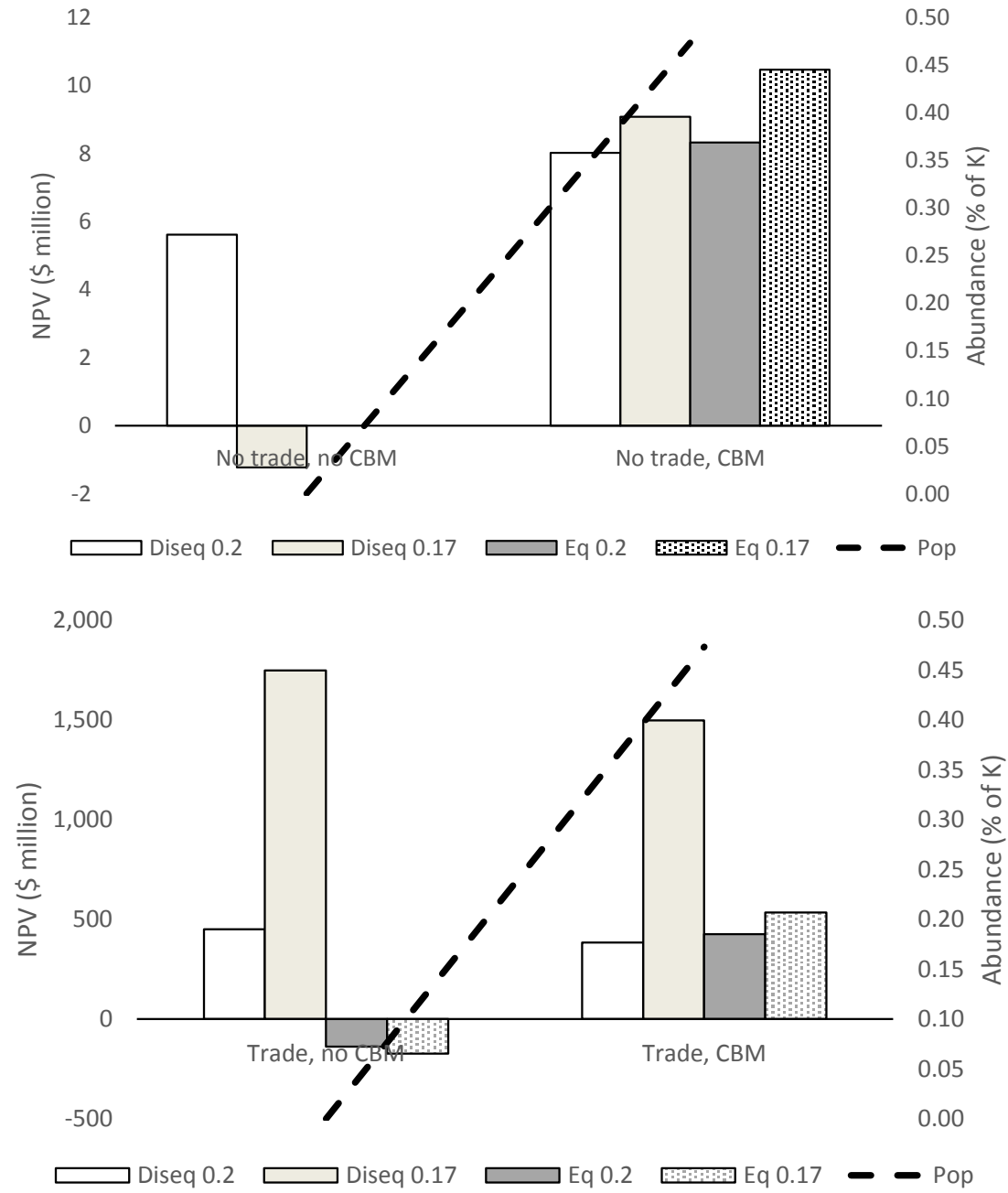
Figure 5: Optimal de-horning rotation time for poachers and game farmers

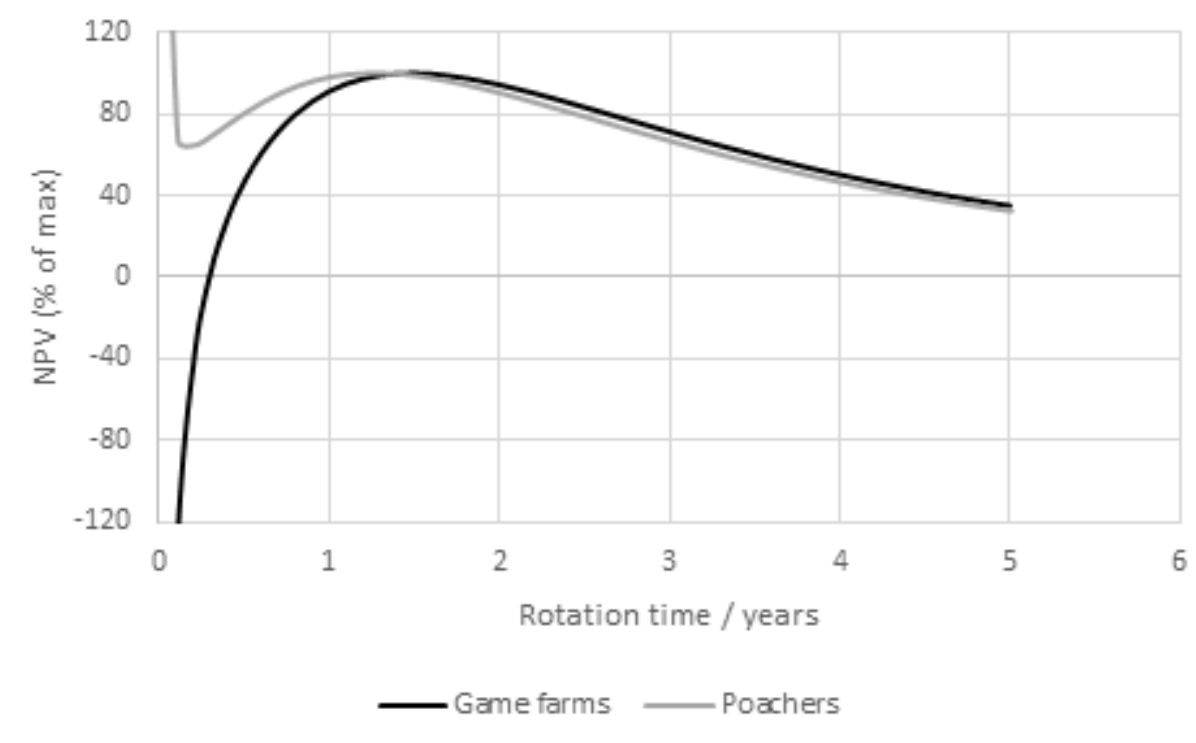




\section{Appendix 1: Estimating the dynamics of game farm income and de-horning costs}

The value of rhinos comprises legal trophy hunting, live sales, game products and ecotourism.

\section{A. Trophy hunting}

In 2012 , the value of rhino hunting dropped dramatically, from $\$ 11,7$ million to $\$ 6$ million (Table A1.1). This represents a decrease of almost 50\% in value from 2011.

Table A1.1. Hunting data

\begin{tabular}{|c|c|c|c|c|c|c|c|}
\hline & Numbers killed & \multicolumn{2}{c|}{ Price } & \multicolumn{3}{c|}{ Total value } \\
\hline & White & Black & White & Black & White & Black & Total \\
\hline & & & $\$ /$ rhino & $\$ /$ rhino & $\$$ & $\$$ & $\$$ \\
\hline 2011 & 137 & 1 & 85,000 & 80,000 & $11,645,000$ & 80,000 & $11,725,000$ \\
\hline 2012 & 67 & 1 & 85,000 & 300,000 & $5,695,000$ & 300,000 & $5,995,000$ \\
\hline
\end{tabular}

B. Live sales

Live auction sales of rhinos indicates a value of $\mathrm{R9,17}$ million in turnover for 2012 , or $\$ 1,07$ million (Table A1.2)

Table A1.2. Average auction prices 2012

\begin{tabular}{|l|r|r|r|r|}
\hline Rhino & Average price (Rand) & Number & Turnover (Rand) & Value (\$) \\
\hline White & & & & \\
\hline Young Bull & $169,090.9$ & 11 & $1,860,000$ & \\
\hline Cow & 317,500 & 8 & $2,540,000$ & \\
\hline Heifer & 247,000 & 5 & $1,235,000$ & \\
\hline Family Group & $207,941.2$ & 17 & $3,535,000$ & \\
\hline TOTAL & & & $9,170,000$ & $1,072,138$ \\
\hline
\end{tabular}

Source: S A Game \& Hunt January 2013, converted to US dollars assuming a 2012 exchange rate of $1 \$=8.553$ rand (www.irs.gov.za)

\section{Game products}

Game products from rhinos could potentially include a range of products, such as meat, skins, and ornamental objects. Van der Merwe and Saaiman (2003) estimate that the value of game products in total is R20 million (2000 values). Rhino sales represent roughly 1,27 percent of total game sales (2012), so game products from rhinos are approximately $\$ 58,556$ after adjusting for Consumer Price Index (CPI) inflation from 2000 to 2012 (CPI 2012=97.8; CPI 2000=49.6).

\section{Ecotourism}

We estimate that 12,857 rhino were in Kruger National Park (KNP) in 2012, or approximately 61,3 percent of the total rhino population. Eco-tourism values are difficult to arrive at, and difficult to apportion to rhino populations. However, rhinos are one of the big five and big five tourism would attract a greater economic rent than non-big five tourism. The approach we use is to utilise the value of eco-tourism expenditure from Kruger National Park as a basis, given the large share of rhinos in this reserve. Turpie and Joubert (2001) estimate that total tourism expenditure at KNP was R136 million (2000 values). Converting to US dollars assuming an exchange rate in 2000 of R4.60796/dollar and inflating to 2012 values using an exchange gives a value of $\$ 58,195,229.63$. We then need to work out rhinos share of this value. Using the share of rhino sales to total game sales 
(2012) as a proxy for rhinos share of value, gives $\$ 739,079(\$ 58,195,229.63 \times 0.0127)$. Dividing by the total number of rhinos in KNP gives a value per rhino of $\$ 57,48$. Multiplying by the total number of rhino in $2012(20,989)$ gives the total value of ecotourism.

\section{E. Total value of rhino products}

Table A1.3 indicates that $72 \%$, or roughly $\$ 6$ million, of total rhino income comes from hunting. Relatively little comes from sales and ecotourism. The total value of income equates roughly to R397 per rhino.

Table A1.3. Total value of rhino products

\begin{tabular}{|l|c|c|c|}
\hline & Value of Rhinos (2012 US\$) & \$/rhino & \% share \\
\hline Hunting & $5,995,000$ & 286 & 72 \\
\hline Sales & $1,072,138$ & 51 & 13 \\
\hline Game products & 58,556 & 3 & 1 \\
\hline Ecotourism & $1,206,544$ & 57 & 14 \\
\hline TOTAL & $8,332,239$ & 397 & 100 \\
\hline
\end{tabular}

\section{F. The dynamics of income and de-horning costs}

The cost of de-horning a rhino is R7000 (2011 values, Hall, 2012). This equates to a value of $\$ 926$ per rhino at a $\mathrm{R} / \$$ exchange rate of 7.562 . Using prevailing $\mathrm{R} / \$$ exchange rates, as well as adjusting for inflation, gives the values and cost and income dynamics over time (Table A1.4). The rand has devalued against the US dollar over the past few years, hence the declining values over time, as shown in the Table.

Table A1.4. De-horning cost and income, 2011-2014

\begin{tabular}{|l|c|c|c|}
\hline & Revenue & Costs & Difference \\
\hline & $\$ /$ rhino & $\$ /$ rhino & $\$ /$ rhino \\
\hline 2011 & & 926 & -467 \\
\hline 2012 & 397 & 864 & -421 \\
\hline 2013 & 358 & 779 & -397 \\
\hline 2014 & 337 & 735 & -429 \\
\hline Average & 364 & 826 & \\
\hline
\end{tabular}

Source: Own calculations based on www.irs.gov (exchange rates) and www.statssa.gov.za (inflation rates) 